\title{
REFORMASI BIROKRASI MELALUI E-GOVERNANCE : PELUANG ATAU TANTANGAN DALAM PELAYANAN PUBLIK ?
}

Zainuddin Mustapa

Fakultas Ilmu Sosial Dan Ilmu Politik Universitas Indonesia Timur Il. Rappocini Raya No.171-173 Makassar Telp.(0411) 421974, Fax (0411) 852111

\section{ABSTRACT}

The government will continue to strive to make efforts to reform the bureaucracy, as an integral part of improving government management and enhance the dignity of the government in the eyes of the international community and the world. However, increasingly based on that, the reform is not easy, because he did not take place in a vacuum chamber. Bureaucratic reforms face cultural constraints, structural and even mental constraints of bureaucracy, in addition to technical constraints. The problems are now required is a renewed commitment of the leaders or officials at central and local levels to continue to push reforms through e-government bureaucracy. Important conclusions can be drawn from this study is that e-government is implemented seriously and consistently will greatly support the transparency of public services. What also must be understood by government officials is that the use of e-government still requires consistent monitoring systems. In addition to extensive knowledge of information technology, e-government must also be supported by good integrity among policy makers and pelaksannya. Teknoogi information does make many things easier and more efficient.

Keywords: Bureaucracy, E-Government, Information Technology

\section{ABSTRAK}

Pemerintah akan terus berusaha melakukan upaya untuk mereformasi birokrasi, sebagai bagian integral untuk meningkatkan manajemen pemerintahan dan meningkatkan martabat pemerintah di mata masyarakat internasional dan dunia. Namun, semakin berdasarkan itu, reformasi tidak mudah, karena ia tidak terjadi dalam ruang vakum. Reformasi birokrasi menghadapi kendala budaya, hambatan struktural dan bahkan mental birokrasi, di samping kendala teknis. Masalah sekarang yang dibutuhkan adalah komitmen baru dari para pemimpin atau pejabat di tingkat pusat dan daerah untuk terus mendorong reformasi melalui e-government birokrasi. Kesimpulan penting yang dapat ditarik dari penelitian ini adalah bahwa e-government dilaksanakan dengan serius dan konsisten akan sangat mendukung transparansi pelayanan publik. Yang juga harus dipahami oleh pejabat pemerintah adalah bahwa penggunaan e-government masih memerlukan sistem monitoring rutin. Selain pengetahuan luas tentang teknologi informasi, e-government juga harus didukung oleh integritas yang baik di antara pembuat kebijakan dan pelaksannya. Informasi teknoogi tidak membuat banyak hal lebih mudah dan lebih efisien.

Kata kunci: Birokrasi, E-Government, Teknologi Informasi 



\section{A. PENDAHULUAN}

Dukungan pemerintah terhadap perkembangan e-government di Indonesia mulai tampak pada periode awal tahun 1990-an, meskipun lembaga-lembaga yang berkompeten bagi pengembangan sistem informasi dalam organisasi publik sebenarnya sudah ada pada beberapa dasawarsa sebelumnya. Terkait dengan pengembangan e-government, pemerintah telah mengeluarkan Inpres No-3 tahun 2003 mengenai Strategi Pengembangan Egovernment. Namun dengan rumusan rencana pengembangan e•government yang masih abstrak dalam aturan tersebut, tampak-nya masih banyak perbedaan pemahaman di antara para pejabat pemerintah sendiri. Dalam pandangan umum, e-government sejauh ini masih dipahami sebatas sebagai pembuatan situs web oleh organisasi pemerintah. Belum banyak yang memahami secara luas bahwa tahap-tahap perkembangan pemanfaatan teknologi informasi dalam organisasi publik itu bisa berbeda-beda mengikuti tuntutan kebutuhan masyarakat yang semakin beragam. Tetapi kurang jelasnya konsep e-government itu dapat dimaklumi karena cakupan tugas-tugas pemerintah yang sangat luas dengan kebutuhan di masing• masing daerah yang beragam.

Secara umum, tahap pengembangan $e$ government dapat dibagi menjadi tiga, yaitu: 1) tahap informatif, 2) tahap interaktif, dan 3) tahap transaktif. Tahap informatif mengandung arti bahwa pembukaan situs web oleh organisasi pemerintah sebatas digunakan sebagai sarana penyampaian informasi tentang kegiatan pemerintahan di luar media elektronik maupun non-elektronik yang selama ini ada. Tahap interaktif berarti penggunaan teknologi internet yang memungkinkan kontak antara pemerintah dan masyarakat melalui situs web dapat secara online sehingga memungkinkan interaksi yang lebih interaktif dan terbuka. Sedangkan tahap transaktif adalah penggunaan teknologi internet yang memungkinkan transaksi pelayanan publik melalui situs web. Misalnya, kemungkinan untuk membayar pajak, melakukan permintaan formulir, atau transaksi lainnya melalui internet. Seperti diketahui tugas utama birokrasi adalah untuk menjalankan pemerintahan dan juga sebagai struktur yang menjamin kelancaran pemerintahan.

Namun pada kenyataannya, birokrasi memiliki kelemahan dalam pelaksanaannya dilapangan, ia memiliki citra buruk yang melekat dalam dirinya (the bad sides of bureaucracy) terutama dalam praktik pelayanan publik sehari-hari, khususnya di Negara sedang berkembang yang mewarisi tradisi birokrasi yang korup dan kurang berpihak pada rakyat yang mestinya mereka layani, diminta ataupun tidak. Apabila kita bertanya kepada kritikus pemerintahan tentang penilaian mereka terhadap praktik birokrasi, maka kita akan mendapatkan gambaran kebalikan dari identitas teoritis sebagaimana yang dikemukakan oleh penggagasnya. Kegalauan itu tidak saja dilontarkan oleh ilmuwan Negara sedang berkembang namun juga dalam banyak kasus di Negara maju.

Secara teoritis pun banyak orang member penilaian negative, sebagian bagian dari sifat birokrasi yang kaku dan formalistis, sebab tidak semua urusan masyarakat dan pmerintahan bisa didekati dengan pendekatan formalistis. Contohnya, orang miskin yang belum memiliki stempel miskin dari birokrasi lokal. Mereka tidak bisa mendapatkan hakhaknya yang asasi misalnya memperoleh perawatan dan pengobatan karena dia tak mendapati dirinya memiliki kartu keterangan miskin. Kritikan itu berisi poin-poin yang umumnya negatif, dapat dilihat seperti contoh berikut ini : [bureaucracy] evokes the slowness, the ponderousness, the routine, the complication of procedures, and the maladapted responses of bureaucratic organizations to the needs which they should satisfy, and the fustations which their members, clients, or subjects consequently endure.

Dikatakan bahwa gambaran bagi organisasi birokratik adalah keadaan yang lamban, yang membosankan, yang rutin, yang rumit prosedunya, dan yang buruk adaptasinya terhadap kebutuhan-kebutuhan yang harus mereka penuhi, dan juga mengingatkan kita akan rasa frustasi yang terus-menerus dirasakan oleh para anggotanya, kliennya atau subyeknya. 
Pengidentikan birokrasi dengan berbagai hal yang bernada negative memang bukanlah sesuatu hal yang baru. Bagi banyak ahli birokrasi tetap memiliki varriasi konotasi, tergantung kelompok social yang menyampaikan keluhan. Golongan tertentu dengan jabatan tinggi mengeluh tentang hilangnya keistimewaan, yang oleh tradisi ada, bisa dibatasi oleh birokrasi. Kalangan pengusaha mengeluhkan campur tangan birokrasi dalam perdagangan, para seniman mengeluhkan pekerjaan tulismenulis mereka yang tak kunjung masuk urusan utama birokrasi, para ilmuwan mengeluhkan kedunguan para pelaksana tugas atau PNS yang bekerja lamban dan seenaknya sendiri, para negarawan mengeluhkan penundaan penyusunan dan pelaksanaan agenda pemerintahan. Dalam sebuah masyarakat dan ekonomi yang semakin digerakkan oleh inovasi teknologi, birokrasi di Negara-negara sedang berkembang harus berhadapan dengan proses tuntutan yang baru yaitu : efesiensi, produktifitas, akses rakyat terhadap informasi yang ada dalam birokrasi serta tuntutan kepastian dan rasa aman dan rasa nyaman (convenience).

Dalam proses Negara yang menuju demokrasi selalu terdapat tuntutan dan bahkan kebutuhan akan hak-hak "masyarakat yang diperintah" harus diletakkan seiring dengan tujuan-tujuan pembangunan. Secara umum diketahui bahwa diluar lingkungan birokrasi, secara historis, inovasi-inovasi teknologi telah menghasilkan kualitas kehidupan yang meningkat dengan kata lain kalau mau maju ya harus ada inovasi.

Bagi seorang pemimpin pemerintahan yang baik, pelayanan yang baik adalah visi yang selalu ingin diciptakannya dalam menjamin perbaikan pemerintahan secara keseluruhan. Dan tampaknya dari ber-bagai segi pemerintahan ada keyakinan : tak ada satu cara yang baku, tak ada "cara terbaik" kea rah pemerintahan yang baik. Dan dalam pekembangannya yang sekarang e-government berhasil-berhasil menjadi alternative yang umum diterapkan di Negara sedang berkembang dalam reformasi pemerintahannya.

\section{B. KONSEP DASAR E-GOVERNMENT}

Pengertian tentang e-government telah banyak dikemukakan para praktisi maupun akademisi sehingga definisi yang ada mengandung penekanan yang berbeda-beda. Bank Dunia (2001) mendefinisikan E-government sebagai penggunaan teknologi informasi oleh instansi pemerintah seperti Wide Area Networks (WAN), Internet, mobile computing) yang dapat digunakan untuk membangun hubungan dengan masyarakat, dunia usaha, dan instansi pemerintah lainnya.

Sedangkan definisi lain mengatakan bahwa e-government adalah penggunaan teknologi informasi untuk membuka pemerintah dan informasi pemerintah untuk memungkinkan dinas-dinas pemerintah untuk berbagi informasi demi kemanfaatan publik, untuk memungkinkan terjadinya transaksi secara online dan untuk mendorong pelaksanaan demokrasic. Selanjutnya variasi tentang definisi e -government dapat disajikan sebagai berikut:

- E-government applies concepts of electronic commerce (e.g. information and marketing through Web sites, selling to customers online) to government operations.

- Refers to the federal government's use of information technologies (such as Wide Area Networks, the Internet, and mobile computing) to exchange information and services with citizens, businesses, and other arms of government.

- Government activities that take place by digital processes over a computer network usually use the Internet, between the government and members of the public and entities in the private sector, especially regulated entities. These activities generally involve the electronic exchange of information to acquire or provide products or services, to place or receive orders, to provide or obtain information, or to complete financial transactions. The anticipated benefits of e-government include reduced operating costs for government institutions and regulated entities, increased availability since government services can be accessed from virtually any location, and convenience due to round-the-clock availabiliry. 
Teman-teman di atas apabila direlokasikan dengan manfaat yang diperoleh melalui penerapan e-government masih sangat jauh. Melalui e-government paradigma pelayanan public bergeser dari paradigma birokratis menjadi paradigma e-government yang mengedepankan efesiensi, transparansi, dan fleksibilitas, yang akhirnya bermuara pada kepuasan pengguna layanan public. Manfaat lain e-government dikemukakan oleh European Commision;

- Transforming government into a dynamic, productivity-driven concept and set of Institutions (for example through re•engineering).

- Providing interactive user-driven services to citizens and businesses which maximise fu46lment and security, whilst generating trust and confidence.

- Using ICT to support good governance so that democracy is characterised by accountability, openness and transparency, and that articulation between the different parts of society, including government, is flexible, effective and beneficial to the common good.

- Supporting the general role of government in underpinning and promoting the wealth, welfare and sustainable development of society.

E -government Indonesia yang masih dalam tingkatan interaksi belum dapat mentransformasi pelayanan publik yang lebih baik. Bahkan untuk komunikasi eksternal pun masih belum dapat dimanfaatkan dengan baik walaupun sarana interaksi yang ada berupa forum, email, chat, polling, dan lainnya sudah disediakan pada setiap website pemerintah. Sarana interaksi belum dapat ditujukan untuk komunikasi formal maupun informal, juga untuk umpan balik langsung yang cepat seperti yang disampaikan oleh Alfred dalam tabel di atas, apalagi untuk sarana providing interactive userdriven services to citizens and businesses which maximise fulfilment and security, whilst generating trust and confidence sebagaimana pendapat European Commision.

Keadaaan di atas, menunjukkan tantangan penerapan e-government di Indonesia masih sangat banyak di antaranya dari segi sumber daya manusia, perangkat keras, dan organisasi. Kemampuan sumberdaya manusia atau peopleware terutama para pejabat birokrasi maupun staff dalam menggunakan Internet yang masih terbatas. Hal ini terbukti dari masih sangat tergantungnya birokrasi dalam pengembangan e-government terhadap pihak luar.

Operasionalisasi e-government juga tidak berjalan lancar ditandai dengan sarana interaksi yang disediakan tidak dimanfaatkan dengan baik. Hal ini membuktikan bahwa paradigma pelayanan publik berbasis $e$ goverment memerlukan persiapan yang lebih serius, bukan hanya implementasi aplikasi saja tapi harus bisa melalukan transformasi budaya, seperti ditekankan oleh Eurepean Commision: "Adding ICT to government services, however, does not itself produce "e-Government" - new technologies must be implemented hand in hand with organisational change and new skills if convenient, service-oriented services are to flow".

Aspek hardware yakni berkaitan dengan teknologi dan infrastuktur juga menjadi tantangan. Terbatasnya hardware dan software serta masih sedikitnya instansi pemerintah yang terhubung pada jaringan baik lokal (LAN) maupun global (Internet) menyebabkan perkembangan e-government tidak dapat berjalan lancar. Sebenarnya melalui implementasi e-government komunikasi internal antar dinas pernerintah dapat lebih terjalin, namun demikian karena keadaan infrastruktur jaringan yang masih terbatas maka e-government akhirnya hanya dimanfaatkan untuk komunikasi eksternal yang juga belum maksimal.

Berdasarkan aspek organisasi atau organoware, seringkali instansi pemerintah dalam mengoperasionalkan e-government menemui kendala dalam aspek organisasi. Kendala ini ditandai dengan tidak fleksibelnya Struktur Organisasi dan Tatakerja (SOT) birokrasi yang dapat mewadahi perkembangan baru model pelayanan publik melalui $e$ government. Para admin e-government di beberapa daerah yang selalu memonitor pengaduan masyarakat tidak mempunyai wewenang dan kemampuan untuk langsung 
berinteraksi dengan masyarakat misalnya dalam memberikan jawaban. Sedangkan untuk meminta pejabat atau pegawai yang terkait untuk menjawab pertanyaan yang telah diajukan masyarakat, para admin tersebut tidak mempunyai wewenang. Hambatan organoware lainnya adalah belum adanya regulasi yang mengijinkan transaksi melalui media elektronik dapat dianggap sah. Walaupun sudah ada Undang-Undang ITE namun belum ada Juklak dan Juknis di samping SOT dan regulasi. Tantangan organoware berikutnya adalah terbatasnya dana yang tersedia untuk pengembangan dan operasionalisasi e-governent di daerah. Pemerintah pusat hanya menyediakan kerangka kebijakan dan panduan tidak disertai dengan alokasi dana sehingga harus ditanggung oleh daerah yang bersangkutan.

\section{E-GOVERNANCE SEBAGAI TREN GLO- BAL MODERNISASI BIROKRASI}

Selama lima tahun belakangan ini, ilmuwan pemerintahan dan juga badan-badan resmi PBB untuk pelayanan publik terus mengevaluasi dan sekaligus mencari strategi yang jitu dalam rangka mengembangkan standar mutu pelayanan publik bagi Negara-negara berkembang. Tidak kurang dari UNPAN (www.unpan.org) dan World Public Sector misalnya, selalu saja mengembangkan ide dan menfasilitasi pengembangan sistem baru dalam rangka perbaikan pelayanan publik (better publik services).

Mengapa perbaikan pelayanan publik dikaitkan dengan keberanian inovasi dalam birokrasi dan pentingnya introduksi IT (Information Technology) untuk perbaikan sistem pelayanan, peningkatan produktifitas, efesiensi dan bahkan demokrasi dan apa masalah yang akan dihadapi Negara-negara berkembang seperti Indonesia?

Dari sisi akademis, seperti telah ada kesimpulan umum, bahwa tren aplikasi e-government dalam pemerintahan serta hasil yang telah dicapai oleh beberapa Negara maju mengesankan bahwa Negara yang ingin memperbaiki pelayanan publiknya, sedikit atau banyak ia harus berani berinovasi dalam manajemen pelayanan dan peningkatan mutu pelayanan publiknya. Dengan kata lain seolah ada adagium : "tidak aka nada perbaikan mutu pelayanan publik tanpa inovasi. Tidak ada inovasi tanpa aplikasi IT dalam birokrasi. Dengan kata lain tidak ada pelayanan yang baik tanpa e-government".

Kutipan pengertian dibawah ini adalah contohnya : Government-a publik organization - is part of a broader governance system. It is a means to a goal. These days, government is seen predominantly as a publik organization set up by a society for the purpose of pursuing that society's development objectives. This comprises articulating the society's development-related demands, proposals and needs, aggregating them and implementing respon sive solution. Enjoyment of publik consent constitutes the source of government's legitimacy. Trans-parency is a condition sine qua non for government's accountability vis-à-vis its oversight body. E-government is a gover-nment that applies ICT to transform its internal and external relationships. Throught the application of IT to its operations, a government does not alter its functions or its obligation to remain useful, legitimate, transparent and accountable. If anything, this application raises society's expectations about the performance of government, in all respects, to a much higher level.

Kutipan di atas memberi pengertian sekaligus penilaian bahwa e-government adalah aplikasi teknologi informasi dan komunikasi dalam dan dengan pihak luar diharapkan meningkatkan performance pemerintahan dan memenuhi ekspektasi masyarakat akan peningkatan kualitas pemerintahan. Demikian pula terbukti semakin maju sesuatu Negara semakin tinggi tingkat e-government.

\section{PERAN NEGARA-NEGARA MAJU MENUJU E-GOVERNMENT}

Deskripsi berikut ini akan menampilkan peringkat kesiapan e-government secara global untuk 25 negara teratas di dunia. Kebanyakan Negara-negara dengan ekonomi maju dan berpendapatan tinggi menduduki peringkat teratas jika dibandingkan dengan rata-rata Negara lain. Meski mayoritas Negara tersebut 
adalah Negara industry maju, namun beberapa Negara berpendapatan menengah dengan ekonomi sedang berkembang atau sedang beranjak menuju maju, memperlihatkan adanya trend "pengejaran akan ketertinggalan".

Peringkat Kesiapan E-Government Secara Global 25 Negara Teatas

\begin{tabular}{|c|c|c|}
\hline NO. & $\begin{array}{c}\text { NAMA } \\
\text { NEGARA }\end{array}$ & $\begin{array}{c}\text { INDEKS } \\
\text { GOVERNMENT }\end{array}$ \\
\hline 1. & Amerika Serikat & 0,927 \\
\hline 2. & Swedia & 0,840 \\
\hline 3. & Australia & 0,831 \\
\hline 4. & Denmark & 0,820 \\
\hline 5. & Inggris & 0,814 \\
\hline 6. & Kanada & 0,806 \\
\hline 7. & Norwegia & 0,778 \\
\hline 8. & Swiss & 0,764 \\
\hline 9. & Jerman & 0,762 \\
\hline 10. & Finlandia & 0,761 \\
\hline 11. & Belanda & 0,746 \\
\hline 12. & Singapura & 0,746 \\
\hline 13. & Republik Korea & 0,737 \\
\hline 14. & Selandia Baru & 0,718 \\
\hline 15. & Islandia & 0,702 \\
\hline 16. & Estonia & 0,697 \\
\hline 17. & Irlandia & 0,697 \\
\hline 18. & Jepang & 0,693 \\
\hline 19. & Prancis & 0,690 \\
\hline 20. & Italia & 0,685 \\
\hline 21. & Austria & 0,676 \\
\hline 22. & Chili & 0,671 \\
\hline 23. & Belgia & 0,670 \\
\hline 24. & Israel & 0,663 \\
\hline
\end{tabular}

Sumber : United Nations ; World Publik Sector Report

Secara keseluruhan, Amerika Utara dan Eropa memimpin di seluruh dunia. Negaranegara Asia Tengah-Selatan dan Afrika memiliki kesiapan e-government yang terendah. Tak diragukan bahwa yang mendasari gambaran ringkas secara agregat ini ialah tingkatan pembangunan ekonomi, social dan politik dari Negara-negara yang bersangkutan.

Salah satu factor primer turut berperan dalam menyumbangkan angka kesiapan $e$ government yang tinggi ialah investasi di masa lalu dalam sumber daya telekomunikasi dan manusia. Rendahnya kesiapan e-government di Asia tengah-selatan dan Afrika merupakan sebuah cerminan dari sangat rendahnya indeks telekomunikasi dan sangat rendahnya indeks Modal Sumber Daya Manusia.

Disparitas dalam tingkat kesiapan e-government bukan hanya mencerminkan rendahnya level sumber daya infrastruktur dan modal sumber daya manusia beberapa bagian di seluruh dunia. Disparitas itu juga menunjukkan besaran kesenjangan yang ada. Indicatorindikator di Amerika Utara dan Eropa sekitar 5 -10 lebih tinggi dalam hal basis sumber daya manusianya dan sekitar 4-20 kali dalam hal pembangunan infrastrukturnya. Sebagai misal, jika AS dijadikan pembanding. Bahkan meskipun 40 persen penduduknya tidak online, tingkat kesiapan telekomunikasi di Afrika dan Asia tengah dan selatan hanya 1/20 dari AS. Asia tengah dan selatan yang merupakan sepertiga jumlah penduduk dunia memiliki sekitar 20 persen dari rata-rata kapasitas modal sumber daya manusia AS. Ebarnya disparitas ini berakhir pada "kesenjangan digital" (digital divide).

Perkembangan teknologi informasi dan komunikasi telah menawarkan solusi untuk meningkatkan kinerja pelayanan publik yang lebih berbasis pada good governance. Pemanfaatan e-government bagi birokrasi diharapkan dapat menjadi alternatif bagi reformasi birokrasi menuju pelayanan yang lebih baik.

Untuk mendukung keberhasilan dalam penerapan e-government, pemerintah pada tahun 2003 telah mengeluarkan beberapa panduan yaitu Panduan Pembangunan Infrastruktur Portal Pemerintah, Panduan Manajemen Sistem Dokumenen Elektronik Pemerintah, Panduan Penyusunan Rencana Pengembangan e-government Lembaga, Pedoman Penyelenggaraan Diklat ICT dalam Menunjang e-government, Pedoman tentang Penyelenggaraan Situs Web Pemerintah Daerah.

Kemudian dilengkapi dengan panduan yang dikeluarkan pada tahun 2004 meliputi: standar mutu dan jangkauan pelayanan serta pengembangan aplikasi (e-services), kebijakan tentang kelembagaan, otorisasi, informasi dan keikutsertaan swasta dalam penyelenggaraan, kebijakan pengembangan pemerintahan yang baik dan manajemen perubahan, panduan tentang pelaksanaan proyek dan penganggaran e-government aplikasi e-government 
pemerintah pusat dan daerah. Kemudian pada tahun 2006, Pemerintah membentuk Dewan Teknologi Informasi dan Komunikasi Nasional (Detiknas) melalui Keppres C-006 yang salah satu tugasnya untuk mempercepat proses implementasi e-government. Namun demikian keberhasilan penerapan e-government belum terlihat signifikan.

\section{E. APLIKASI E-GOVERNMENT DI NEGARA BERKEMBANG}

Terdapat harapan bahwa masuknya IT dalam birokrasi dan terdapatnya keberanian inovasi dalam berbagai hal akan menghantar pemerintah pada fase kemajuan seperti yang dicapai oleh dunia industry, perbankan dan perguruan tinggi di luar instansi pemerintahan. Tak bisa dipungkiri bahwa jika sebuah Negara atau subsistem pemerintahan telah berani mengintroduksi kegagapan teknologi atau kesenjangan digital (Digital Divide), hal itu akan membuka kesempatan yang luas bagi pencapaian pembaharuan di subsistem yang lain.

Hal ini berlaku bagi semua Negara, seberapapun level pembangunan ekonomi mereka, level pembangunan sumber daya manusia mereka dan apapun konteks social dan cultural yang ada dalam komunitas atau Negara tersebut. Jika bisa mengatasi GAPTEK dan berani bertarung melawan cara-cara lama yang lamban dan birokratis maka harapan akan kemajuan lain akan tercapai.

Penggunaan dan optimalisasiteknologi dasar dan menengah dalam birokrasi memungkinkan berlangsungnya komunikasi internal dan eksternal pemerintah secara cepat, tepat, sederhana berjangkauan luas dan memiliki kesanggupan menjalin jaringan. Inovasi dan introduksi IT dalam birokrasi bisa dimanfaatkan untuk menurunkan biaya dan meningkatkan efektivitas, yang merupakan dua fitur yang diinginkan dari semua kerja pemerintahan, dan yang terutama dalam hal pelayanan publik.

Penggunaan dan optimalisasi mesin yang tepat dalam subsistem birokrasi juga bisa digunakan untuk optimalisasi waktu, dimana komunikasi dapat dilakukan dari luar jam kantor sekalipun dan dari jarak yang amat jauh sekalipun. Apabila sistem IT digunakan jam kerja bisa bertambah 24 jam setiap sehari administrasi publik yang berfungsi 24 jam setiap hari selama 7 hari seminggu, yang memiliki transparansi dan akuntabilitas, terbentuk jaringan kerja, dan memiliki manajemen iformasi dan penciptaan pengetahuan. Selain itu, IT bisa memberikan perlengkapan kepada masyarakat untuk bisa berpartisipasi secara sungguh-sungguh dalam sebuah proses politik yang inklusif sehingga melahirkan dukungan publik yang selalu mengikuti informasi (well-informed) yang merupakan basis yang paling utama bai legitimasi pemerintahan.

Dari sudut pandang ini, inovasi di tangan pemerintah bisa menjadi sebuah alat yang efektif untuk menambahkan nilai publik. Jelas, maksimalisasi nilai publik pada akhirnya akan bergantung pada penentuan mengenai kapan, bagaimana dan dimana memanfaatkan kapasitas-kapasitas komunikasi yang baru yang bisa didapat oleh pemerintah lewat aplikasi IT dalam kerja mereka.

Masalah lain dalam inovasi dan penggunaan IT khususnya di Negara-negara sedang berkembang seperti Indonesia adalah terbatasnya keterampilan dan kultur birokrasi sipil. Pegawai negeri sipil haruslah sanggup dan bersedia untuk mendukung e-government atau setidaknya harus bersedia belajar dan berubah. Kultur yang ada dalam tubuh birokrasi sipil menentukan penilaian terhadap kemungkinan kehilangan yang akan dihasilkan oleh penerapan e-government terhadap individu pegawai negeri sipil dan juga terhadap kekuatan dan efektivitas dari lobi anti-perubahan.

Demikian juga dengan masalah koordinasi. Koordinasi dan upaya yang dibutuhkan baik dalam maupun antar pemerintah haruslah diperkuat terlebih dulu sebelum aplikasi $e$ government diterapkan untuk menghindari penggandaan, menjamin interoperabilita dan memenuhi ekspektasi-ekspektasi para pengguna. Kerangka legal, e-government memunculkan kebutuhan-kebutuhan legal yang khusus dan hal ini harus disadari dan dihadapi sejak awal. Infrastruktur harus dinilai berdasarkan latar belakang kebutuhan dan hasil yang diinginkan. Keterbatasan infrastruktur akan membatasi hasil maupun pengembangan yang direncanakan. Sebaliknya, jika 
berlebihan melampaui kebutuhan, ada bahaya dan akan menjadi perlengkapan yang membebani kantor yang mahal dan mubazir.

Pemimpin sektor publik harus berkomitmen terhadap e-government, memimpin dan membangun dukungan luas baginya, dan berani untuk belajar. Hal ini akan menghadirkan tanda-tanda positif yang sangat penting yang dibutuhkan oleh birokrasi sipil dari pucuk pimpinannya. Publik harus memiliki keterlibatan pribadi dalam pengembangan e-government. Hal ini harus diperkuat dengan secara aktif, sungguh-sungguh dan kontinyu mengundang partisipasi masyarakat dalam pengembangan aplikasi e-government sehingga aplikasi IT akan membentuk kebiasaan hidup dan kerja masyarakat. Harus ada visi dan rencanarencana untuk menjembatani jurang-jurang yang ada dalam keterampilan dan akses. Jika tidak, baik administrasi publik maupun masyarakat tak akan bisa berharap akan bisa melek dan sanggup menggunakan IT, yang merupakan bahan penting bagi keberhasilan e-government. Juga dalam hal ini diperlukan Kemitraan.

Sejak awal, pemerintah harus melihat organisasi-organisasi di luar pemerintahan sebagai mitranya dalam ha sumber keuangan, peningkatan keterampilan, akses yang lebih baik dan kapasitas yang memadai untuk membentuk jaringan IT. Kemitraan tak boleh dijalin dengan mengorbankan transparasi, akuntabiltas atau kelayan investasi secara ekonomis. Juga perlunya monitoring dan evaluasi. Menetapkan tanggung jawab yang jelas dan tolak ukur yang realistis bagi pengembangan e-government merupakan sebuah bahan penting bagi keberhasilan yang akan dicapai dan bagi pembangunan transparansi dan akuntabilitas secara menyeluruh dalam sector publik.

Alasan mendesak bagi para pengguna $e$ government adalah persepsi akan nilai tambah. Setiap rancangan pengembangan e-government haruslah memasukkan sebuah perhitungan nilai tambah yang bisa diberikannya kepada individu penggunanya. Hal ini paling bisa dicapai jika perhitungan tersebut dengan perhitungan para pengguna. Akses dan keterampilan. Penerapan e-government haruslah dilakukan sedemikian rupa sehingga para pengguna potensial e-government bisa betulbetul memanfaatkannya secara mudah dalam hal waktu, biaya, dan usaha. Solusi-solusi imajinatif bagi peningkatan level kemudahan penggunaan ini haruslah menjadi bagian dari setiap rencana pengembangan e-government. Solusi-solusi tersebut harus dipertimbangkan, namun sekaligus mentrasendensi, tingkat akses dan keterampilan individu.

Privasi dan keamanan. Factor keamanan dan privasi apapun pendefinisiannya secara cultural-haruslah ditegaskan sejak awal secara terbuka dan ditangani secara potensial. Publik dibatasi untuk tidak melanggar wilayah privasi dan rahasia ini dan setiap berita (bahkan yang bersifat informal) harus dibatasi agar tidak menjadi sebuah kemunduran yang besar yang memiliki konsekuensi-konsekuensi jangka panjang. Seperti kita ketahui, didalam desakan masyarakat akan pelayanan publik yang baik, proses pembangunan yang mengharuskan keterlibatan pemerintah, masyarakat dan synergy dunia luar. Penerapan e-government paling baik jika dilakukan dalam bidang-bidang yang dianggap sebagai terkait erat dengan prioritas. Kebutuhan-kebutuhan pembangunan oleh masyarakat. Alasan lain mengapa harus inovatif ialah tuntutan efisiensi dan efektivitas sebagai criteria kunci sukses pemerintah.

Namun harus diakui banyak masalah terjadi kalau IT diterapkan ditengah setanah seperti yang kita lihat bahwa kemampuan pemerintah untuk menggunakan IT dalam gerak kerjanya dibatasi oleh kondisi ketersediaan pendanaan (awal). Bukan operasi awal proyek percontohan e-government harus dimulai dengan pemahaman yang baik mengenai biaya yang dibutuhkan dan dengan menjamin pendanaan setelah dilakukan analisis yang seksama terhadap biaya penerapan. Manakala mungkin dan layak, pendanaan tersebut harus dipandang sebagai sebuah investasi bisnis dan bisa diharapkan akan menghasilkan kembalian.

\section{F. CATATAN AKADEMIK E-GOVERNMENT DAN PELAYANAN PUBLIK}

Menurut hemat kita, upaya dalam rangka untuk memperbaiki birokrasi kita, sistem 
birokrasi, pembenahan personel maupun budaya yang melingkupinya, dan aplikasi IT dalam birokrasi memang penting. Cepat atau lambat Indonesia akan mengejar efisiensi dan produktifitas pelayanan publiknya sesuai dengan demand masyarakat sekitarnya. Dengan kata lain fasilitas e-government di tingkat pusat dan propinsi di Indonesia memang perlu mendapat dukungan yang pantas.

Pengalaman banyak Negara mengisyaratkan, bahwa apabila dalam periode yang terlalu panjang, suatu birokrasi tak kunjung menampakkan kesungguhannya termasuk dalam peningkatan pelayanan publiknya maka trust kepada pemerintah akan turun dan pemerintah akan selalu tertinggal dalam memperbaiki diri.

Di Indonesia, pembenahan birokrasi biasanya dilakukan melalui pendekatan incremental, perubahan yang sedikit demi sedikit, dengan harapan antara lain agar didapatkan perubahan yang terencana (guidance development). Demikian pula introduksi IT dalam pemerintahan akan menyertai pembenahan peningkatan mutu pelayanan. Terlalu tinggi nafsu untuk mentransformasikan birokrasi tradisional dengan modernitas akan bisa berakibat ongkos social politik yang terlalu mahal, misalnya robohnya berupa jaminan kelanjutan tersedianya lapangan kerja dalam pemerintahan yang tak tergantikan oleh mesin. Tapi, masalahnya ialah, transformasi semangat pemerintahan yang modern dengan menggunakan teknologi komunikasi dan informasi ke dalam kalangan birokrasi, tidaklah simple. Ia akan menghadapi berbagai pintu-pintu (barier) antara lain, berupa pertanyaan berikut ini;

Pertama, mulai dari manakah transformasi itu dilakukan? Sebab pada prakteknya nanti, orang akan dihadapkan pilihan-pilihan yang beragam. Sebab adalah sulit mentransformasi ide itu pada semua level birokrasi, desa/kelurahan, kecamatan, kabupaten/kotamadya, level propinsi, level pusat atau keseluruhan secara berbarengan. Dan, pilihan-pilihan strating point itu akan membawa konsekuensikonsekuensi sendiri. Pilihan harus dimulai secara berbarengan, umpamanya, membawa konsekuensi: mudah diucapkan, sulit dilaksanakan karena mekanisme evaluasi jadi bias.
Kedua, oleh siapakah atau lembaga apakah yang bertanggung jawab sebagai pelaksana dalam kaitan transformasi jiwa wirausaha ini dalam sistem birokrasi?. Sebab selama ini, instansi yang terdekat dengan tugas pembenahan, semisal Depdagri, Menkominfo, Lembaga Administrasi Negara (LAN), Kementerian Negara Peningkatan Aparatur Negara, atau bahkan induk-induk departemen belum tampak secara institusional mengagendakan transformasi jiwa entrepreneur ini sebagaimana yang diidealkan dan diangankan banyak orang. Walaupun, dimeja-meja diskusi mereka menyetujui ide ini.

Ketiga, sudah adakah atau apa sajakah isi (content) dari proses transformasi itu, yang dapat dijadikan bahan rujukan spesifik dari proses dalam birokrsai kita?. Persoalan yang muncul kemudian adalah, belum adanya mekanisme transformasi inovasi dan IT ini dalam sistem kelembagaan pemerintah dimana mereka bekerja. Jadi justru tataran sistemnya yang belum siap menerima usulan ini. Masuknya jenis-jenis tugas-tugas baru dalam pemerintahan; yaitu industrialisasi, perdagangan antar Negara, investasi asing, pengelolaan bantuan luar negeri, hal-hal baru yang yang berkaitan dengan otonomi daerah, mengharuskan pejabat di daerah bekerja dengan kemampuan yang optimal. Apabila prasyarat diatas dapat terpenuhi maka harapan akan peningkatan pelayanan publik akan dapat ditingkatkan dalam waktu cepat.

\section{G. KESIMPULAN}

Kinerja $e$-government Indonesia belum dapat dirasakan secara signifikan baik oleh pihak internal maupun eksternal pemerintah. Beberapa tantangan dan hambatan masih banyak yang harus dihadapi. Namun demikian seiring dengan telah disahkannya Undangundang tentang Informasi dan Transaksi Elektronik (UU ITE) maka terbesit harapan e-government akan dapat lebih dirasakan oleh masyarakat. Di samping itu pemerintah juga sudah mengeluarkan statemen yang akan menurunkan tarif Internet sampai 40\%, hal ini akan semakin memberikan peluang yang lebih besar bagi penerapan e-government 
untuk masa yang akan datang.

Menjadi sangat penting sekarang ini adalah pembaharuan komitmen para pemimpin atau pejabat di tingkat pusat maupun daerah untuk terus mendorong reformasi birokrasi melalui e-government. Kesimpulan penting yang dapat ditarik dari studi kasus kedua kota ini ialah bahwa e-government yang dilaksanakan secara serius dan konsisten akan sangat menunjang transparansi pelayanan public. Yang juga harus dipahami oleh para pejabat pemda ialah bahwa pemanfaatan e-government tetap memerlukan sistem pengawasan yang konsisten. Selain pengetahuan yang luas tentang teknologi informasi, e-government juga harus didukung oleh integritas yang baik di antara para perumus kebijakan dan pelaksannya. Teknologi informasi memang membuat banyak hal semakin mudah dan semakin efisien.

\section{DAFTAR PUSTAKA}

Albrow, Martin, 1970. Bereaucracy, New York, Praeger Publisher

Luthans, 1989. Fred Organizational Behaviour, $4^{\text {th }}$ Edition. Mc Graw-Hill Series in Management.

Said, M. Mas'ud, 1987. Perspektif perilaku birokrasi. Jakarta Rajawali , 1997. Debirokrasi

Birokrasi Indonesia, UMM Press Malang,

,2007. Birokrasi di Negara Birokratis, UMM Press Malang.

Thoha, Miftah, 2002, Reformasi birokrasi Pemerintahan. Seminar Good Governance di Bappenas.
Anonim. (2007). "Ada TI Ada Reformasi Birokrasi”, majalah e-Indonesia, Vol III (20).

Garson, D. (1999). Information Technology and Computer Applications in Public Administration: Issues and Trends, Hershey: Idea.

Senn, J A. (1990). Information Systems in Management, California: Wadsworth.

Wilcoks, L. \& Harrow, J. (eds.) (1992) Rediscovering Public Service thlana-gement, London: McGraw-Hill.

Yusof, M.M. (2005). Information Systems and Executives'Role: The Pre-electronic Government Era Experience, Selangor: Utusan.

Heeks, R. (2005). The Implementation of Information Systems in Public Organisations.

Indrajit, R.E. (2002). Electronic Government, Yogyakarta: Andi Offset.

Kumorotomo, W\& Margono, S.A. (2004). Sistem Informasi Manajemen dalam Organisasi Publik, Yogyakarta: Gama Press.

Rosenau, James N (2007), “Governing The Ungovernable: The Challenge Of A Global Disaggregation of Authority", Regula-tion \& Governance (2007) 1, pp 88-97.

Rouben, L. (ed.). (1999) Citizens and the New Governance: Beyond New Public Management, Amsterdam: IOS Press.

Starling, G. (2006). Managing the Public Sector, Boston: Wadsworth Publishing.

Stiglitz, J. (2005). Globalization and Its Discontents, New York: New Harper. 